\title{
REFLEXIONES EN TORNO A LE CORBUSIER DIBUJANTE, PINTOR Y ESCULTOR INICIADOR DEL PURISMO
}

ELIA ESPINOSA

A la memoria de François Châtelet, magnífico hombre, historiador y filósofo

\section{Introducción}

Venerado como a un dios de la visualidad y del manejo de los volúmenes en el espacio y del espacio entre volúmenes, o visto como un artista que sólo trabajó a su manera, sin mayor novedad, las corrientes plásticas de los años 1916 a 1930 aproximadamente, en Europa, Le Corbusier es menos, o muy mal, conocido como dibujante, pintor y escultor, que como arquitecto y urbanista.

Cuando escuchamos su nombre, vienen al pensamiento sus arquitecturas sobriamente funcionalistas o el tropel de curvas y luz dentro de una magnífica armonía que es la Capilla de Ronchamp. Pero sería raro, por lo menos en México, que pensáramos en sus primeras pinturas puristas o en sus estupendas esculturas funcional puristas o, mucho menos, en los extraordinarios sensuales y vitales dibujos de cuerpos femeninos en diversas actitudes, casi todas deliciosamente eróticas.

A través de largo tiempo de estudio de la obra en general del maestro suizo-francés, una se percata de que son su pintura y su dibujo el germen de los manejos del espacio que llevó a cabo en su escultura y en su arquitectura, esta última trabajada, más de una vez, con la intención de quien hace una escultura. El tratamiento de tensiones, distensiones, reducciones formales y espaciales bajo la luz, que realizara en sus planos arquitectónicos y para un determinado terreno geográfico, se encuentra en sus pinturas y dibujos, ejecutados entre 1918 y 1930 . En esos trabajos puso en 
práctica los principios del Purismo, aunque esta corriente fue teóricamente formulada conjuntamente con Amedée Ozenfant, a principios de los años veinte, en París.

A partir del análisis de quince obras del artista que son muy significativas de cada terreno de su trabajo, trazamos algunas reflexiones en torno al purismo, a la línea, al tiempo, al espacio, a la importancia del diagrama y de la monumentalidad en su concepción y concreción en las obras.

\section{Albores del Purismo}

Le Corbusier pintó su primer cuadro, La chimenea, en 1918 (fig. 1). Se trata de un juego de prismas y una horizontal que atraviesa la tela dividiendo en dos niveles el espacio; al centro, sobre la línea divisoria, hay un cubo solo y puro; debajo de esa línea, a la izquierda, aparecen dos libros cuyos lomos están colocados horizontalmente hacia nosotros. La coloración es tímida, muy tenue, drásticamente subyugada por el diseño. Es visible en él la imperiosa necesidad de dividir el espacio para mostrar su relación pura y lenta, o arrebatada, con las formas primarias. "Tomar posesión del espacio, dirá, es el primer gesto de lo vivo... La arquitectura, la escultura y la pintura son específicamente dependientes del espacio y también necesitan administrarlo." "La llave de la emoción estética es una función espacial." ${ }^{2}$

Cuando Le Corbusier pintó ese cuadro ya había construido la Casa Fallet (1905-1906), en La Chaux de Fondes, las Villas Stotzer y Jacquemet (1908), la Villa Jeanneret-Perret (1912), la Villa Favre-Jacot (1912), La Villa Schwob (1916) y diseñado los Mataderos en Burdeos y Chaully (1917). Había experimentado su primer enfrentamiento romántico con la arquitectura, dibujado formas naturales (pinos, flores y animales del bosque aunque todavía no la figura humana). También había leído a Ruskin, a Edward Schurés, en quienes advirtió tanto la admiración apasionada por la naturaleza (profesada por Ruskin), como la idea de que el espíritu humano como elemento primordial del progreso histórico y la "grandeza humana", pueden rejuvenecer la civilización moderna. De aquí que siempre, tanto en sus planos y edificios como en sus dibujos más pequeños,

\footnotetext{
${ }^{1}$ Le Corbusier, "L'Espace Indicible", en: Le Corbusier-Savina, dessins sculptures. Introduction de Françoise Franclieư, París, Fondation Le Corbusier-Philippe Seres Éditeur, 1984, pp. 23-24, p. 23. Traducción de Elia Espinosa.

Ibidem.
} 
sus pinturas, y esculturas, respetara la naturaleza esencial y textural de los materiales y de los objetos, admirara la máquina, creyera en el espíritu humano y en el trabajo como fuerza futura. Todo se ordenaría en pro de las formas bajo la luz, orquestadas, según palabras suyas, por un juego sabio, correcto y magnífico compuesto por contrastes.

La chimenea es el primer paso hacia el purismo, corriente que inició con su amigo, el pintor y crítico Amedée Ozenfant en 1918. Tendencia de carácter perfeccionista y riguroso, el purismo fue toda una resultante filosófico- práctica de su revisión poético-geometrista del cubismo de Braque y Picasso, y de la aceptación de que existen objetos-standard en la realidad cotidiana, dignos de formar parte de la investigación artística. Además, el Purismo hizo resurgir la geometría como único orden con posibilidades de salvar el caos de la post-guerra a través de su intromisión emotivo-constructiva en la arquitectura, la pintura y la escultura.

La chimenea significa también el inicio de una revaloración más de la naturaleza muerta como ámbito de trabajo en el que, a través del silencio y el estatismo determinantes, se libran todas las batallas nuevas y viejas entre el orden, la norma, el color, la línea y el espacio. La naturaleza muerta se convirtió, según Curtis, en un resquicio investigador de la vida moderna. ${ }^{3}$ Sin explorar y excavar en este género de la pintura, Le Corbusier no hubiera podido madurar sus ideas arquitectónicas principales, ni sus más encendidas pasiones plásticas.

La pureza y la perfección son ideales que se alcanzan y se pierden continuamente durante toda la vida. Pero entre su logro y su muerte está su infinita aportación de novedad y limpieza, de frío nihilismo necesario para que nazcan nuevos seres de sensibilidad y de razón (como llamaba Spinoza a las ideas y a los sentimientos). Por eso el cubo sobre la mesa del cuadro La chimenea, por eso los lomos de los libros reducidos a rectángulos en la parte baja del cuadro, por eso el blanco puro del aire de esta obra. En esta etapa todo quiere alcanzar la pureza, precisión y perfección mecánicas entendidas, claro está, como provenientes del carácter movible del movimiento per se, pero también como imitación de la pulcritud funcional de la máquina, símil de creación puramente humana de la topología de la anatomía y la fisiología orgánicas.

De 1918 a 1925, Le Corbusier y Ozenfant exaltaron apasionadamente las cualidades de la máquina y de acuerdo a ella establecieron las bases estructurales de su obra. En su libro Art, Ozenfant impregnó la imagen de

\footnotetext{
${ }^{3}$ William J. R. Curtis, Le Corbusier, ideas and forms, Phaidon, Oxford, 1986, p. 50. Traducción de Elia Espinosa.
} 
la máquina de una carga religiosa, pues veía y presentía que su gran capacidad de precisión, movimiento y estructura sólo podían tener un contacto místico con el mundo de las matemáticas y una gran fuerza vital, ya que modificaba tanto la vida cotidiana como las concepciones estéticas de la sociedad.

En todos los grandes escritores y artistas de los años 20 en Francia, encontramos si no una alabanza directa a la máquina, sí una alusión a la mecánica fisiológica del cuerpo y a su anatomía en general. A la vez que se alude al cuerpo, a sus funciones perfectas y a la estética experimental, que se apoya en lo orgánico y en el estudio de los sentidos, los escritos están paradójicamente inundados de la palabra Espíritu, escrita con E mayúscula. "Cientificismo" y "espiritualidad" son las dos tensiones determinantes de las ideologías artísticas de esa época.

En el periodo de caos de posguerra que se vivía, se suscitaron varias posibilidades de instaurar un nuevo orden. Para Le Corbusier fue la intuición de un espíritu nuevo, espiritu de creación y de sintesis según él mismo, que por medio del arte daría solución a sus contrastes y tensiones.

El cubismo, corriente que se desenvolvía a la par que el Purismo y otras corrientes pictóricas y que, según Le Corbusier, había "magnificado el espacio por sus hálitos maravillosamente creadores, abriendo una extraordinaria puerta a la investigación pictórica, no guarda nada relativo a los tesoros de la realidad". ¿Qué quiso decir con esto último? Los objetosstandard y el juego de tensiones entre las formas y el espacio darían la respuesta.

Braque y Picasso habían comenzado, hacía casi 10 años, su revolución cubista, descomponiendo los objetos en varias facetas para presentar su totalidad temporal sobre la tela. Convirtieron a la pintura en un laboratorio intelectual que a pesar de haber innovado de raíz sus métodos y concepciones, puso en segundo término a los objetos mismos, por su insistencia en la relación tiempo-espacio-descomposición respecto de la superficie bidimensional.

Le Corbusier y Ozenfant, en cambio, desarrollarían su ejercicio plástico explotando la capacidad o potencial de cada objeto en relación sintética y reductiva con el espacio y con los otros objetos o cosas que les son vecinos en la realidad circundante, y en la pura realidad geométrica y pictórica de la tela. Es obvio que la forma llevaría la batuta en todo esto, y que el color, utilizado en extensiones planas, sólo modularía tensiones, relajamientos,

4 "L'Espace Indicible", op cit. 
posibles "distancias", sensaciones, intenciones, proporciones en el seno de la obra.

Expresar la sensibilidad del espacio y el tiempo como línea

Naturaleza muerta con pila de platos, de 1920 (fig. 2), fue la primera cristalización importante de los esfuerzos investigadores de Le Corbusier. En ella es notable la búsqueda purista, el respeto religioso a la autonomía de los objetos, en los cuales no busca descomposición alguna sino su pura esencialidad hacia las formas primarias puras. Líneas rectas, curvas, el cilindro, el cono, aunque no la esfera en este caso, se yuxtaponen entre sí de acuerdo a los tensores fundamentales. Entre éstos se distinguen, primero, el de la vertical que surge de la espina del libro y sigue en la parte superior de la guitarra, y segundo, de la horizontal que atraviesa, como diámetro, el primer plato de la pila y continúa por la espina de la guitarra. El sistema tensional de esta obra parte de una "cruz griega", para expanderse en el silencio de un mundo geométrico esencial en donde no se habla, no se cuenta nada, todo está ahí, moviéndose en su idea y vibración cromática dentro de una perfecta lentitud.

Es curioso cómo tanto en esta obra como en otras que pintó el maestro, la búsqueda de armonía purista, que implica de alguna manera un análisis, un "despedazamiento" de los objetos y sus formas por lo menos en el proceso pensante, llegue a la extrema lentitud, a una lentitud integradora que nos permite "ver" el tiempo. He aquí una de las aportaciones profundas del purismo a la investigación pictórica de nuestro siglo, a la cual no han aludido otros estudiosos. Mientras el cubismo nos presenta el tiempo a través de la descomposición multifacética de los objetos, ofreciendo así el aspecto sincrónico del tiempo mismo, la obra purista nos deja sentir el tiempo como transcurrir sin límites, lo "aplana", lo vuelve lineal, le da un supuesto principio y un hipotético fin hermanado a la lentitud. Nos permite ver y sentir la velocidad y movimiento de nuestra propia percepción y pensamiento. "El tiempo, la cuarta dimensión, es subjetiva, de naturaleza indudable pero indefinible. ${ }^{5}$

Picasso apronta el tiempo, no lo deja darse cuenta de sí mismo; Braque lo aletarga; Le Corbusier lo doma, le hace aprender la lentitud sobre una superficie. Rectas y ondulaciones, pero un dominio final de curvas, es lo

\footnotetext{
${ }^{5}$ Ibidem
} 
que produce esa serie de sensaciones entre fondo marino y cinematografia en cámara lenta.

Dentro del movimiento de Stijl, Mondrian estatificó el tiempo al imponer verticales y horizontales sin más. En su obra, los colores primarios consolidan la conjura de las rectas que encarcelan al espacio en pro de una pureza en la que los sentimientos no deben tener cabida, y en lo cual siempre debe haber un resquicio para la divinidad. También gracias a la lentitud, Le Corbusier nos hace sensible lo que Boccioni ya había vuelto escultura, para colmo de milagro plástico: la sucesión de estatismos que forman el movimiento. Así como la línea es una sucesión de puntos, el movimiento es una sucesión de estatismos. Boccioni trabaja la sucesión del movimiento en alta velocidad.

En la Naturaleza muerta con pila de platos, el color produce la sensación de lejanía o acercamiento, calor o frío, aunque es evidente que no hablamos de perspectiva con punto de fuga-profundidad. El color y los "tensores" vivifican una dinámica lentamente expansiva en planos que se suceden a pesar del nudo central que la equilibra. La Casa Citrohen tiene esa misma "perspectiva", pero forzosamente en perspectiva aérea, ya que realiza la bidimensionalidad de lo trazado en la tela, en las cuatro dimensiones del espacio real. Las líneas se aproximan "hombro con hombro", se moldean apretándose una contra otra. Como si aludiera a esto, el pintor afirmó: "El dibujo presenta a primera vista un grafismo muy cerrado, especie de norma opuesta a lo fluido, a lo que corre, a la facilidad ... contornos impecables, repertorio previamente establecido, pero simplemente destinado a expresar la sensibilidad del espacio dentro del ordenamiento de objetos entre sí, su 'sinfonía', sus distancias y sus relaciones, este es el principio mismo del dibujo purista." ${ }^{\text {"6 }}$ Si abstraemos, se diría que en esa Naturaleza..., cual una rueda de ferrocarril, la pila de platos y la espina de la guitarra van a desplazarse sobre su propio riel.

Como Juan Gris para el cubismo, Le Corbusier introdujo la luz en sus pinturas. Una pura luz cromática, no proveniente de intensión iluminadora alguna, o de la intención de entrometer la luz natural en sus telas se refracta hacia el espectador. Pero en Vaso y rollo de papel blanco, y en su boceto previo (fig. $\overline{3}$ ), vemos, como excepción de lo anterior, la invasión brillante de la luz natural, aunque siempre con el afán de no perder de vista la composición geométrica purista y la reducción de los objetos a su más estricta esencia. (Naturaleza es de un gran silencio metafísico. Luz,

\footnotetext{
${ }^{6}$ Texto de Le Corbusier, en: Le Corbusier Secret, introduction de Erica Billeter, Bern, [s.e], 1983, p. 143.
} 
nitidez y dinámica horizontal, vertical y diagonal determinan con gran suavidad su composición misteriosamente perfecta.) ${ }^{7}$

El Purismo magnificó los objetos en su esencia y forma elementales. No fueron sacrificados en pro del análisis, sino en pro de una máxima economía sometida a una constante tensión que apela a las fuerzas de la sensación (no de la emoción) cromática con el plano, el emplazamiento y el corte, totalidad orquestada por la luz.

En Naturaleza muerta roja con violin, 1920 (fig. 4), priva la tensión horizontal, las verticales se concentran en la parte inferior del cuadro. Es visible que en esta época el violonchelo, el violín y todos los objetos o instrumentos curvos lo fascinaban por su capacidad formal tendiente a la lentitud. Por lo regular, en su obra, la lentitud siempre encuentra un desdoblamiento, o más aún, una especie de sombra que quizá represente la sombra de la perfectibilidad del Topus Uranus platónico, aparte de ser un factor de equilibrio de tensiones. Asimismo, en la parte baja del cuadro el blanco resulta un distensor lumínico del grupo de objetos, que equilibra conjuntamente con la franja superior blanca-sepia, tanto proyecciones visuales y lumínicas, como sensaciones cromáticas y dinámicas. Se trata de una obra de oposición de fuerzas con sentido anteroposterior. $^{8}$

Quizá el violonchelo en posición horizontal, tranquilo y potente en la plenitud de sus formas, represente o simbolice la perfección alcanzada por la geometría y la música. Más tarde, esta vehemencia se vio prolongada en sus interpretaciones violentas y pulposas del cuerpo femenino. Desde 1920, el elemento violonchelo, la curva y la huída horizontal de la curva como fondo de montaña geométrica, se vuelven un estribillo en ciertos cuadros del artista. Así, en Naturaleza muerta con muchos objetos, de 1923 (fig. 5), se aprecia el paisaje "curvas-montaña-violonchelo" extenderse en los fondos de ambos cuadros, sobre todo en el segundo, en donde ya no el

\footnotetext{
${ }^{7}$ Recordemos que el Purismo es la etapa platónica y ascética de Le Corbusier pictóricamente hablando, aunque de alguna manera tambien fue, si no política, sí social en cierto sentido, ya que rescata en sus bases teóricas, la serialización de los objetos-standard y la ciega continuidad productiva de la máquina. La luz, el color, la serialización, la negación de todo adonno o decoración que ya había promulgado la Bauhaus en Alemania, fueron desarrolladas por Le Corbusier en sus trabajos de la década 20-30.

${ }^{8}$ En la cinta Gritos y susurros, de Igmar Bergman, hay una escena próxima a esta Naiuraleza muerta de Le Corbusier, por su plasticidad y organización espacial: dos mujeres vestidas de negro dialogan, todo sobre un fondo rojo intenso. No se escucha el diálogo, sólo la música del violoncello que interpreta una sonata de J S. Bach. Las dos obras fueron creadas en contextos muy diferentes y por personalidades generalmente opuestas, pero la conducción de la plástica aunada al significado, crea semejanzas entre los dos artistas.
} 
instrumento musical sino su mera representación esencial constituyen la zona de tensión máxima. La complejidad y refinamiento visual de la $\mathrm{Na}$ turaleza muerta con muchos objetos anuncia casi el fin de la etapa purista de objetos-standard de Le Corbusier. Su búsqueda reductivo-esencial llega a una exacerbación que anuncia, tal vez, una recurrencia que dará paso a otra etapa llamada, por él mismo, de los objetos de reacción poética, en 1925. Numerosas formas se yuxtaponen, se entremezclan como micas de colores diferentes, descontrolan los ojos en su trasjuego realista-abstrayente. En la obra mencionada, cuya dinámica se escucha, el color tiene también la misión de hacer vibrar la superficie y de producir un sonido cromático, como el de una máquina que nos permite ver sus partes interiores en atareada función. Cuando empezó a trabajar con Savina, el gran ebanista francés, en 1945, hablaba de "plástica acústica, es decir, de formas que susurran o resuenan y a la vez escuchan".

Si apelamos a una interpretación psicologista diríase que en Naturaleza muerta con muchos objetos el pintor resume sus múltiples obsesiones estéticas: la antigüedad clásica, el violonchelo, la perfección musical y geométrica, la pasión por el movimiento de la curva y la vehemencia por el color, aunque todavía terroso e impuro, no como los primarios que utilizó en sus esculturas y volúmenes arquitectónicos.

En la época purista, Le Corbusier deja sentados todos los principios estéticos que desarrolló tanto en su arquitectura como, de diversa manera, en sus dibujos eróticos y en su escultura. La tensión, freno y a la vez vorágine de las formas en su relación con otras formas vecinas en el espacio, y estado de la materia sin el cual no habría no sólo arte posible sino tampoco vida orgánica o inorgánica, se anuncia plenamente comprendida y sentida en la época purista, sobre todo entre figura y campo espacial. Este aspecto guardó como lo han mostrado varios estudiosos de Le Corbusier, muy estrecha relación con su tarea fundamental de arquitecto. Algunos de sus manejos espaciales arquitectónicos son reflejo constructivo de ciertos cuadros puristas en cuanto a la posición de masas contra membranas superficiales y los contrastes agudos de sombra y luz. En su mentalidad todo está regido por una estricta diagramación constructivoluminiscente.

\section{Diagrama, línea y dibujo}

En la diagramación preparatoria de Le Corbusier se advierte que el emplazamiento, el plano y el corte o sabiduría para advertir la necesidad de 
límite, permanecen como principios y fines básicos de su organización espacial.

La diagramación, la sensibilidad emplazante y, en consecuencia, la vital importancia del plano y el corte son elementos imprescindibles a una obra artística. La diagramación es imperativa, de obvia importancia en la tarea de un arquitecto, el plano mismo. En la pintura purista de Le Corbusier pre-existe como un íntimo deseo de ordenar en acuerdo a leyes propias que se producen en la pareja obra-creador. Su diagramación está obviamente establecida como sustento o plano de lo que será la pintura. Ya antes de plasmarla, hay un sometimiento al orden, un rigor con miras a la tensión armónica total, gracias a las formas y al color. ${ }^{9}$

La sensibilidad emplazante de Le Corbusier es desbordante en la época 1920-1930; sabe en dónde está cada objeto, cómo está, porqué está ahí, en un lugar determinado, aunque este emplazamiento surja de la diagramación de la obra misma y viceversa. Al hablar de cómo hacer una pintura, Le Corbusier aludió tácitamente al diagrama: "El orden para hacer una pintura es trazar primero un esquema, entonces se toma algún color y se extiende con los pinceles. La recompensa a una larga preparación de práctica y meditación es que el artista no necesita experimentar mucho sobre la tela; plasma ideas que, ya maduras sólo tienen que ser expresadas. ${ }^{10}$

En los años veinte Le Corbusier planteó su dialéctica clásica de la pasión: rigor, tensión, contención, al lado de un romanticismo exacerbadamente parco, reservado, insinuado como elemento de la Antigüedad Griega. Es evidente su deseo de reducir todo cuanto veía a la más económica expresión formal, para resaltar mejor la esencialidad de los objetos de la realidad circundante. Fue en esta época en la que también planteó, a través de su propia obra, el postulado de que la ciencia no puede ser sin el arte, y viceversa, aunque prive en los resultados de sus propias obras el arte sometido a la ciencia y al funcionalismo. El arte debe regresar a la ciencia experimentadora, repetitiva, a fin de crear la "máquina de conmover". En ese periodo todavía hay un subyugo del juego y el azar por el rigor, y será

\footnotetext{
${ }^{9}$ En obra de pintores como Bacon o Pollock, en la cual creeríamos que no hay diagramación ya que es de una evidente anarquía, sí la hay, y muy rigurosa, sometida a su propio "orden ca6tico" invisible. Es el "orden visionario" que ya existe cuando el artista comienza su trabajo y cuando, por ejemplo, llega a exclamar: "ya sé cómo va a quedar esto desde el principio" o "no sé por dónde voy", antes de haber dado la primera pincelada o lanzado el primer chorro de color. Picasso, por ejemplo, originaba y asesinaba constantemente sus diagramas en el acto de pintar, levantar la pintura de las telas, volverla a aplicar de nuevo, etcétera.

${ }^{10}$ Le Corbusier Secret, Op. cit.
} 
en la arquitectura en donde ese planteamiento trascenderá, quedando más en el ámbito de una práctica sensitivo-imaginaria, como es toda base elemental artística. Este manejo de constantes y propuestas de Le Corbusier provoca el conflicto en la oposición entre dibujo y color, idea y forma, y la falacia: "el arte es opuesto a la ciencia".

Desde el punto de vista de la historia del arte, Le Corbusier es un artista renacentista pues, como Leonardo, trabaja de acuerdo a presupuestos eminentemente modernos que incluyen tanto el carácter experimentador, repetitivo y sustitutivo de los términos y elementos de un aparato analítico, como las imágenes y los conceptos dominados principalmente por la fuerza de la imaginación, la sensibilidad y la intuición pura. Leonardo al realizar hermosos dibujos de olas imaginarias, y Le Corbusier al trazar los planos urbanísticos de ciudades que no se realizaron, y que pueden constituir grandes proyectos de magnoesculturas en potencia, son vivos ejemplos de esos procesos.

No se puede hablar del resquicio más pequeño e íntimo de la obra de Le Corbusier sin referirse constantemente a su teoría arquitectónica, plena de rigor conceptual y de poesía. Así como resulta imposible comprender su arquitectura sin conocer los secretos del purismo pictórico. Si no, sería como hablar del mar, su materia y sus criaturas, sin hacer referencia a su colosal totalidad. Desde el menor apunte hecho en esos papelitos que uno saca nerviosamente del saco o el suéter para fijar con avidez una idea, hasta el más complejo y acucioso plano urbanístico o la sistemática pintura purista, la línea y el dibujo llevan la verdadera línea roja invisible, conductora de sus absolutos plásticos.

Le Corbusier siempre se interesó, fundamentalmente, por la forma y la idea sustentadas por una máxima pureza del dibujo (la línea sistematizada), que es un mundo aparentemente cerrado, limitativo, y a la vez un medio de expresión de lo que él llamaba "sensibilidad del espacio". Esta frase es absolutamente poetizadora y personificadora del espacio, lo ve y siente como una matriz que recibe y también prodiga, no como un ámbito que contuviera pero no fuese capaz de dar vida.

No obstante las diversas maneras plásticas y de expresión que su dibujo adoptó durante las diferentes etapas de su carrera, Le Corbusier, como hiciera Leonardo hace cinco siglos, concibió el dibujo como medio de conocimiento, clasificación, escrutinio, retención de las múltiples formas y "maneras de ser" de la naturaleza. Es un instrumento maravillosamente maleable y poderoso para interrogarla, para arrancarle los secretos a la forma y para expresar la "sensibilidad del espacio". Y no sólo la línea negra sobre blanco fue válida, sino también la colorida que, además tiene la 
virtud de clasificar y hacer demostraciones. Como Cocteau, por ejemplo, creyó en la línea visible y en otra invisible que teje el elán de las cosas, ambas subyacentes en la escritura-dibujo y el dibujo-escritura. ${ }^{11}$

\section{La línea y el color en la figura femenina. La monumentalidad}

En Le Corbusier, la línea fue vertical, severa horizontal, pero también línea que vibra, serpentea en una extensa sensualidad. En sus numerosas parejas de mujeres haciendo el amor, o bailando, o sentadas en contemplación, o que contraponen fuerzas y posturas en las que Le Corbusier adoraba dibujarlas advertimos una contundente libertad de expresión. La línea dibuja, configura apasionadamente los volúmenes o simplemente enmarca extensiones. En sus dibujos que, en general, denominamos eróticos (no todos lo son, aunque nos presenten temas que comúnmente tildamos con ese término), el color tiene lógicamente el papel de construir masas, acentuar densidades, extorsionar las formas para dirigirlas en todos sentidos. Pero antes que esto, marca y maneja, distribuye, administra la tensión entre campo y figura, y la mutua lucha de tensiones surgidas principalmente de la contraposición de direcciones entre los cuerpos femeninos, gigantescos la mayoría de las veces. La etapa purista había terminado cronológicamente en 1928, pero siempre subyació como primer alimento en todos los trabajos de Le Corbusier.

Fue en ese año que Le Corbusier introdujo la figura humana en su obra. Esto nos apoyaría para afirmar que en su época purista no quiso utilizarla en sus composiciones porque ella, aún tratada "inexpresivamente", alude de alguna manera a sentimientos o implicaciones morales. En este sentido, Le Corbusier estuvo muy cerca de Kandinsky, Herbin y Mondrian en sus intentos de no alterar con impurezas humanas la pristinidad, la sencillez, el silencio de sus mundos geométricos en los que sólo la divinidad (Mondrian) o los mandatos del espíritu y el pensamiento (Herbin, Kandinsky), puros abrevaderos de la verdadera pintura, debían regir. Introdujo una figura humana franca y naturalmente aliada a la curva, a lo masivo, al volumen y la plenitud vital que siempre admiró en la naturaleza: la figura femenina.

\footnotetext{
${ }^{11}$ Al subrayar con colores diferentes un texto, estamos acentuando o desvaneciendo el peso específico de cada frase o palabra. Y así como en un dibujo constructivo, nuestras ideas e imágenes se van literal y cromáticamente organizando, acentúan variadamente sus dimensiones en el ojo y el pensamiento; no es lo mismo escribir un texto o frase acerca de la luz con tinta amarilla, que con negro o rojo; la luz será otra y la misma
} 
En sus Desnudos azul y rojo, de 1928 (fig. 6) realizados sobre una página de L'Esprit Nouveau, revista de la cual fue promotor, es visible la influencia de las gigantas corriendo sobre la playa, de Picasso. Ese gigantismo ensordecedor con el cual el malagueño marcó un aspecto de su etapa clásica, influyó de manera determinante en Le Corbusier. Como proceso, nunca le llamó la atención la destrucción de la forma que hiciera el maestro español, aunque sí la gran sensibilidad para masificar, sentir los volúmenes en toda su potencia, dinamizar los diversos campos y centros de una pintura... La giganta roja se adelanta, la azul se retiene hacia un fondo verde que neutraliza el espacio para que éste sea solamente un plano luminoso. (Más tarde, en 1950, realiza uno de sus planos reguladores, el de la ciudad hindú Chandigarh el cual, lleno de romanticismo y sensualidad, se mantiene vecino de los dos desnudos, en el que masa y sentido de los volúmenes en contraposición, caracterizan la obra).

La bailarina de flamenco, de 1950 (fig. 7), es una vorágine de dinamismo en que la línea sólo demarca, reforzando la espacialidad vertiginosa del azul y el movimiento mismo de la figura. De nuevo surgen los opuestos azul-rojo (frío-calor); intensificación de un espacio puesto en combate consigo mismo a través de planos diferentes, un verdadero "acontecimiento gráfico" que guarda simultáneamente el rigor monacal trabajado en la época purista y la voluptuosidad del torso desnudo de la bailarina. La capacidad de síntesis de esta obra es totalmente maestra y no divorciada de ese "acontecimiento gráfico", al que hace alusión el artista (frase con la cual define sintéticamente el dibujo), ya que aparte de hacer definitivo un juego de tensiones en el personaje, capta la sucesión cinética de su figura. Más que nunca, excepto en obras arquitectónicas con tendencia al infinito, en su ir más allá de normas y reglas (como la Capilla de Ronchamp), en estos dos trabajos y en otros a lápiz o a pluma, como Desnudo, de 1950 (fig. 8), Mujeres haciendo el amor, de 1950 (fig. 9), Le Corbusier exaltó la intención, la sensación y la emoción, etapas fundamentales de la práctica artística.

Para él, como para Stravinsky, su "alma gemela" en muchos aspectos de la teoría artística, la intención es un fenómeno primordial para el nacimiento y despliegue de una obra. Sin la intención en La bailarina ... hubiese sido imposible que se desencadenaran la sensación o la emoción, uno de los puntos máximos del goce estético.

La intención es el momento de la decisión en que el amor y el pensamiento se unen hacia la consecución de una empresa. La sensación es el momento neuro-espiritual en que la reconstrucción de una totalidad, o por lo menos de una parte de la misma, se nos hace instantáneamente presente y nos comunica toda su vitalidad, energía y posibilidades. La 
emoción, plenitud expansiva que culmina el proceso tanto de creación como de expectación posterior a la creación, es un estado de clímax ascendente. Por eso el espacio, única realidad en que el infinito alcanza su máximo sentido de contención y expresión destructora u originadora, es para Le Corbusier un milagro que acompaña a la emoción plástica: "Ignoro el milagro de la fe, pero vivo con frecuencia el del espacio inefable, coronación de la emoción plástica. ${ }^{12}$ Esta bella confesión, sólo comparable al gozo del orgasmo como absoluta expansión de un estado óptimo sólo vivible, nunca pensable en los momentos de su acontecer, haya realidad en el soberbio dibujo de la bailarina y en el desnudo de la mujer voluptuosa a línea, o en las curvas de la Capilla de Ronchamp, Chandigarh o en la sola preocupación del artista por la manera en que la luz entra en un recinto. No pocas veces, el arquitecto se preguntó obsesivamente: "¿Cómo entra la luz en un recinto? ${ }^{\text {13 }}$

La luz es un constante soslayo con la monumentalidad. No extraña que un arquitecto maneje con más o menos maestría la monumentalidad, pero no es común que un dibujante, un pintor o un escultor monumentalicen, voluntaria o involuntariamente, sus figuras sobre el papel o la tela. La monumentalidad, realidad que se define en términos de expansión, tendencia a la masificación con propensión a separarse de las dimensiones físicas humanas, es una determinante casi connatural a la arquitectura edilicia. Las épocas, las ideologías y la voluntad creadora modulan el carácter monumental; no es lo mismo un edificio musoliniano que la Pirámide del Sol, o las pirámides egipcias, que un rascacielos newyorkino. Todos son diferentes, de monumentalidad muy específica. No olvidemos que aún en el limbo de lo grande, la diferencia se disputa innúmeros matices de grandeza.

Así como la monumentalidad se desenvuelve en primera instancia, en una tendencia hacia lo grande, posee la magia de ser monumental no sólo hacia lo grande o infinitamente grande, sino también hacia lo pequeño e infinitamente pequeño. Como Picasso, Le Corbusier se desboca en su fuerza y movimiento, expande sus límites sobre un papelito, logrando la sensación de pequeña monumentalidad. La monumentalidad es un ensanchamiento del centro vital de un espacio limitado que se realiza en la reducción del espacio que lo rodea, y que se va disminuyendo en un acto a la vez de crecimiento de lo monumental y de reducción del espacio que

\footnotetext{
12 "L'Espace Indicible", Op cit.

13 "Communication à la Réunion Volta, à Rome", en: Le Corbusier-Savina, Op. cit., p. 21.
} 
lo contiene. La muerte de la monumentalidad estaría en el cese de vida de ese "centro centrífugo", y en el rompimiento de sus propios límites. Por eso, a la zaga de lo monumental hay también una simbiosis de tensiones y distensiones muy fácilmente visibles, sobre todo en la pintura.

Le Corbusier se desenvolvió constantemente entre lo monumental grande y lo monumental pequeño, encontrando o fijando ese juego, el cual nos proyectó en la escultura con el ritmo de una cámara de cine que se acerca y aleja velozmente de su objetivo. Hay, digamos, un punto medio de equilibrio de la monumentalidad tanto en su escultura como en su Modulor (2.26 m), medida a la escala humana, "humanización de la medi$\mathrm{da}^{n}$, cuya teoría desarrolló en la obra que lleva ese título.

Pasar constantemente del espacio del papel o la tela al manejo del espacio en la escultura o la arquitectura, es constante enriquecimiento y pérdida, o mejor dicho, una secuencia de sustituciones en donde los sentidos se dilatan, se esquematizan, bajan, suben, serpentean tanto y tan intensamente como la manipulación y la modulación de la materia y los materiales que el artista emplea. El artista se contiene, se hunde, como sus propias formas, en el espacio. Hay una simbiosis entre movimientos máximo y mínimo entre él y esas dos instancias. Al hacer alusión al uno, mágicamente se hace referencia a las otras y viceversa.

\section{El escultor}

Como escultor, Le Corbusier dejó una consistente obra, aunque, claro está, su escultura no sólo fue por "excavación" directa sobre el material, sino por construcción.

Se distinguen tres tipos de esculturas en la obra de Le Corbusier: las puristas, las que yo llamo acústico-primitivas (a partir de los propios términos del artista) y las arquitectónicas, que guardan una muy estrecha relación con las anteriores, y que son, junto con las "acústicas", siempre tendientes a la monumentalidad.

Las esculturas puristas, como Formas en el espacio de la década de los cuarenta (fig. 10) y Escultura policromada, de 1945 (fig. 11), vuelven realidad palpable varios de los principios de sus cuadros puristas: la tensión, la tendencia al logro de un todo armónico-geométrico, o mejor dicho arquitectónico, teniendo en cuenta que "...todo objeto construido por el espíritu humano, que surja a la visualidad, forma bajo la luz", ${ }^{14}$ es digno de

${ }^{14}$ Ibidem, p. 18. 
DOI: http://dx.doi.org/10.22201/iie.18703062e.1990.61.1579

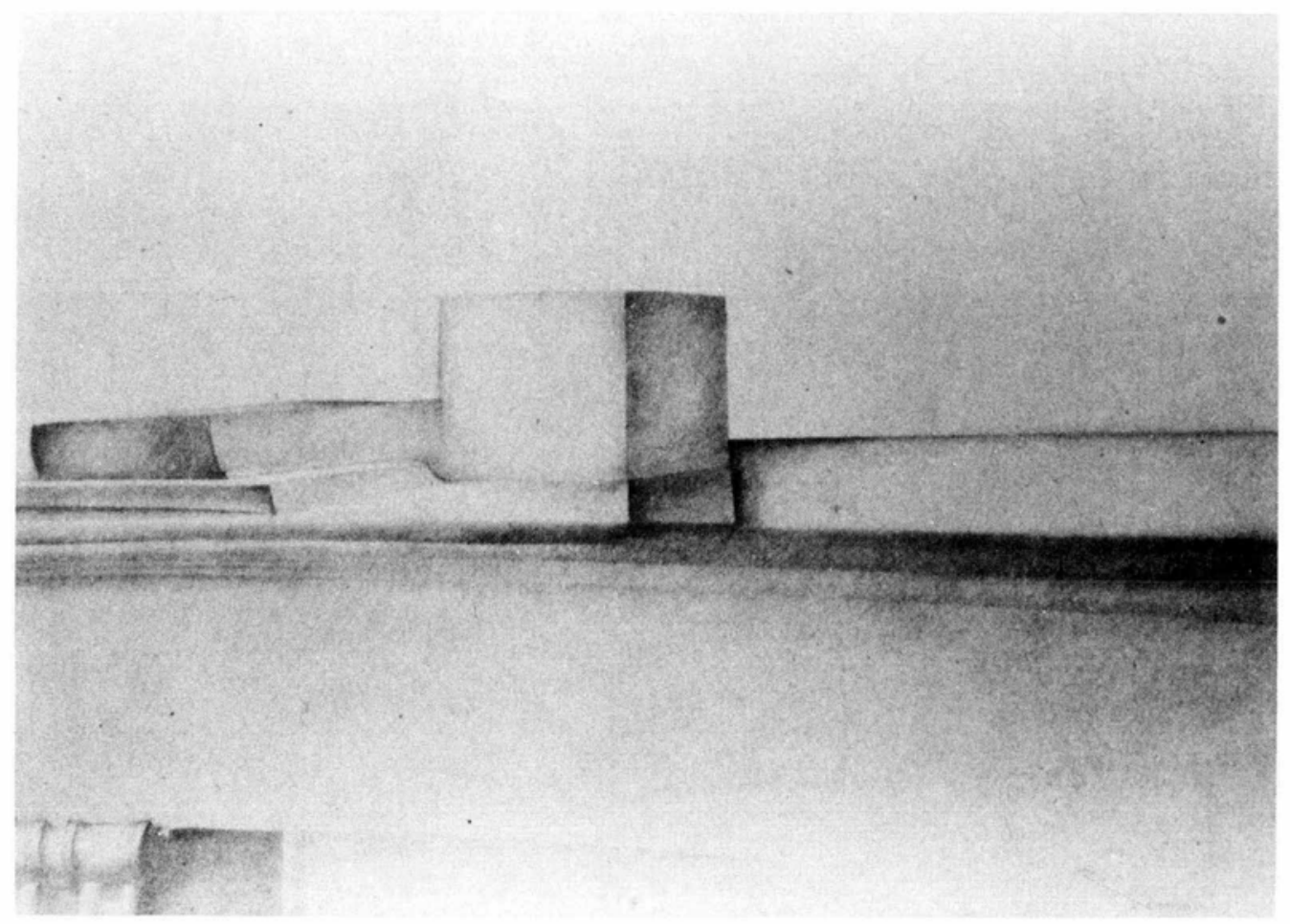

1. La chimenea, 1918

Lápiz / papel. 
DOI: http://dx.doi.org/10.22201/iie.18703062e.1990.61.1579

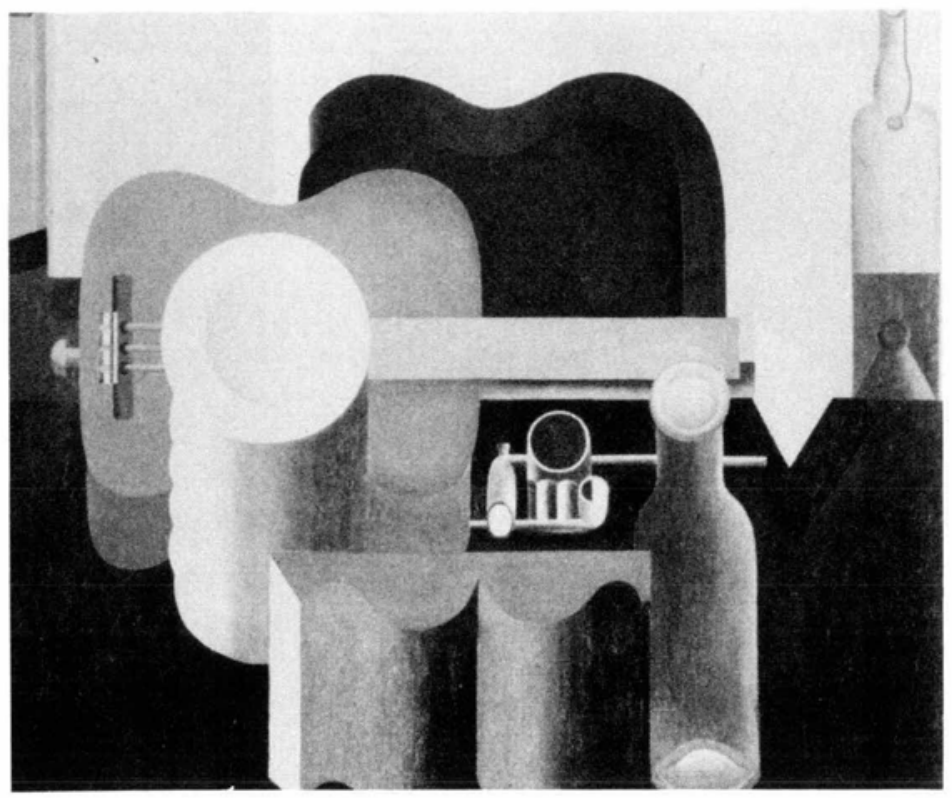

2. Naturaleza muerta con pila de platos, 1920. Oleo / tela.

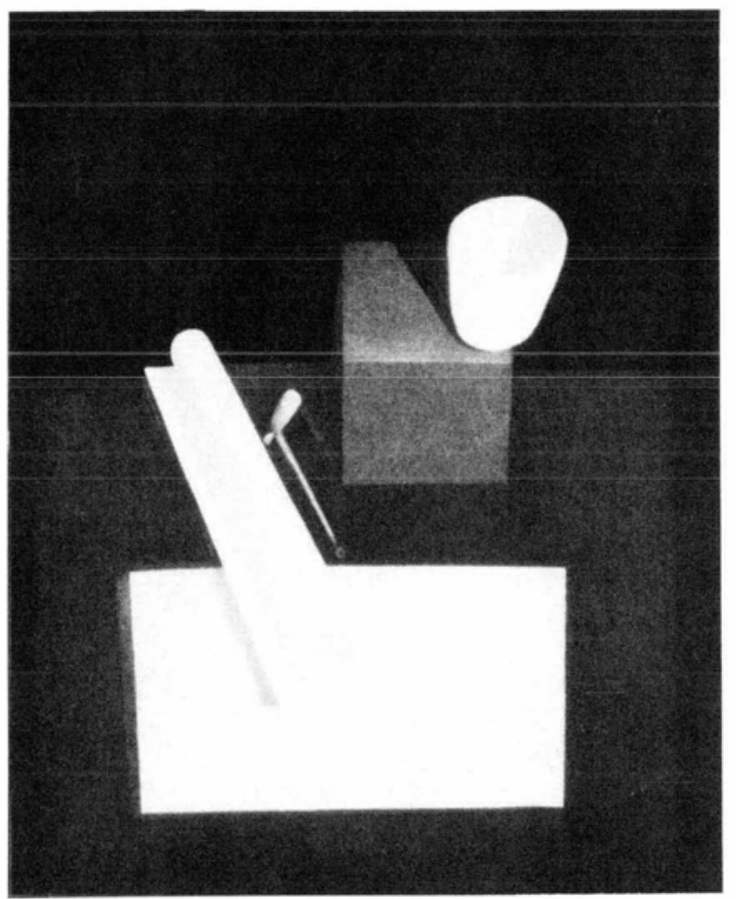

3. Vaso y rollo de papel blanco, 1920. Oleo / tela. 
DOI: http://dx.doi.org/10.22201/iie.18703062e.1990.61.1579

4. Naturaleza muerta roja con violin, 1920.

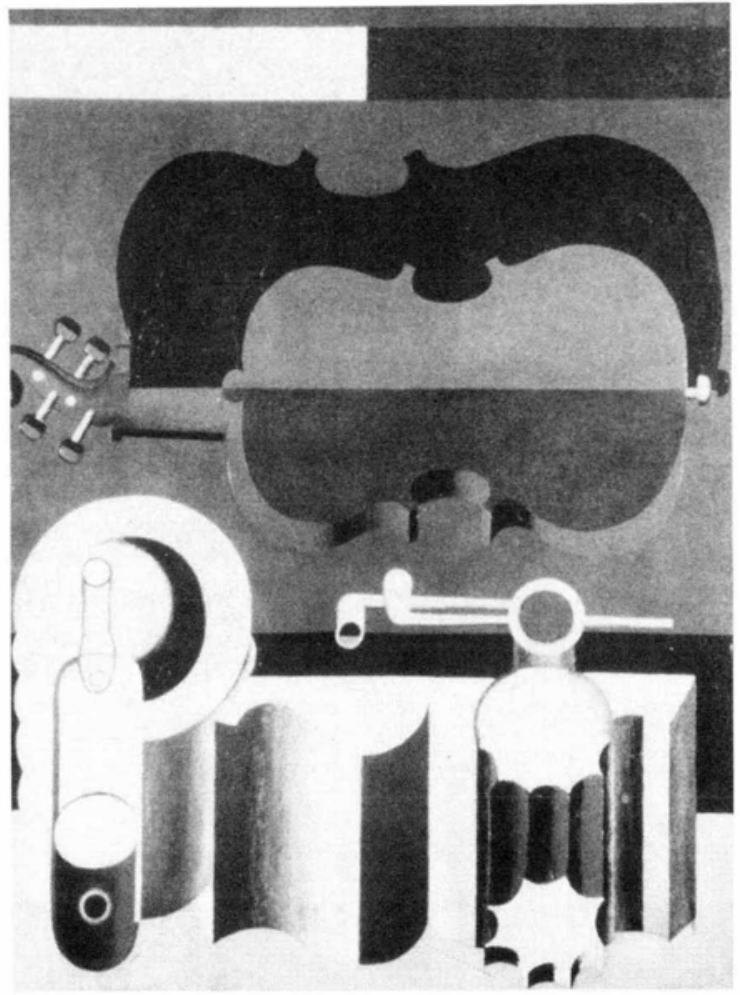

5. Naturaleza muerta con muchos objetos, 1923. Oleo / tela.

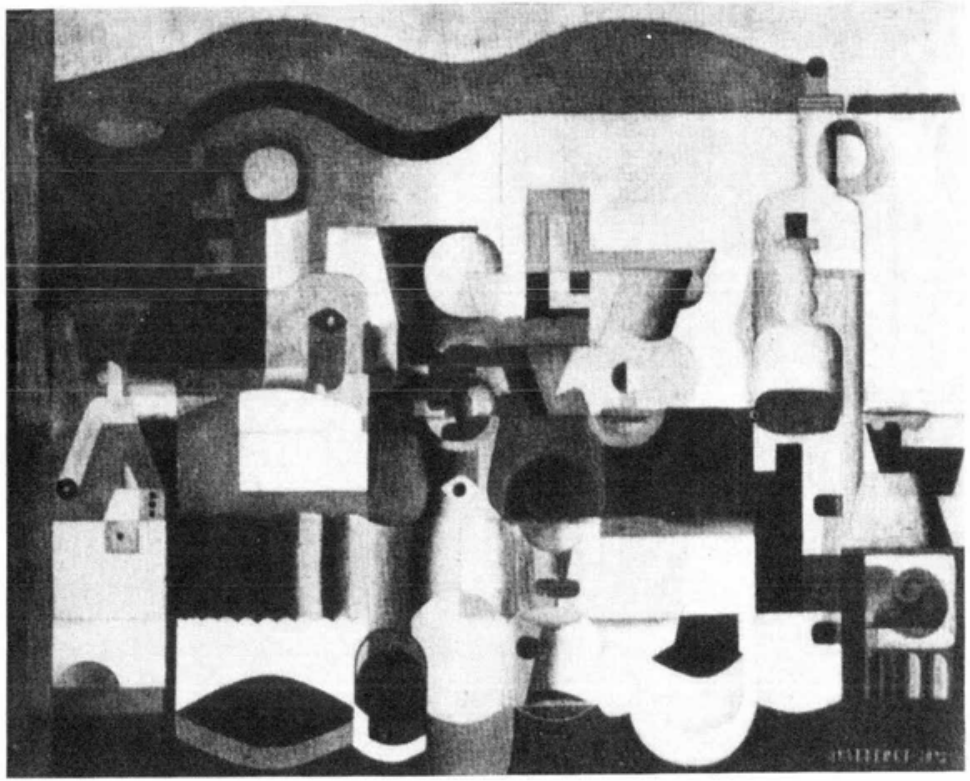


DOI: http://dx.doi.org/10.22201/iie.18703062e.1990.61.1579

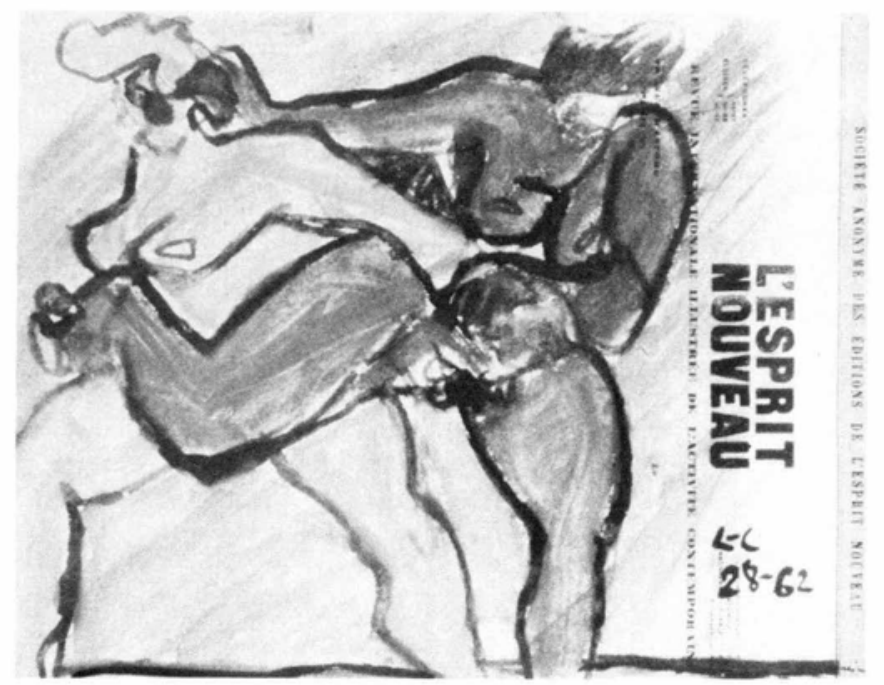

6. Desnudos azul y rojo sobre una página de L'Esprit Nouveau, 1928. Gouache sobre papel.

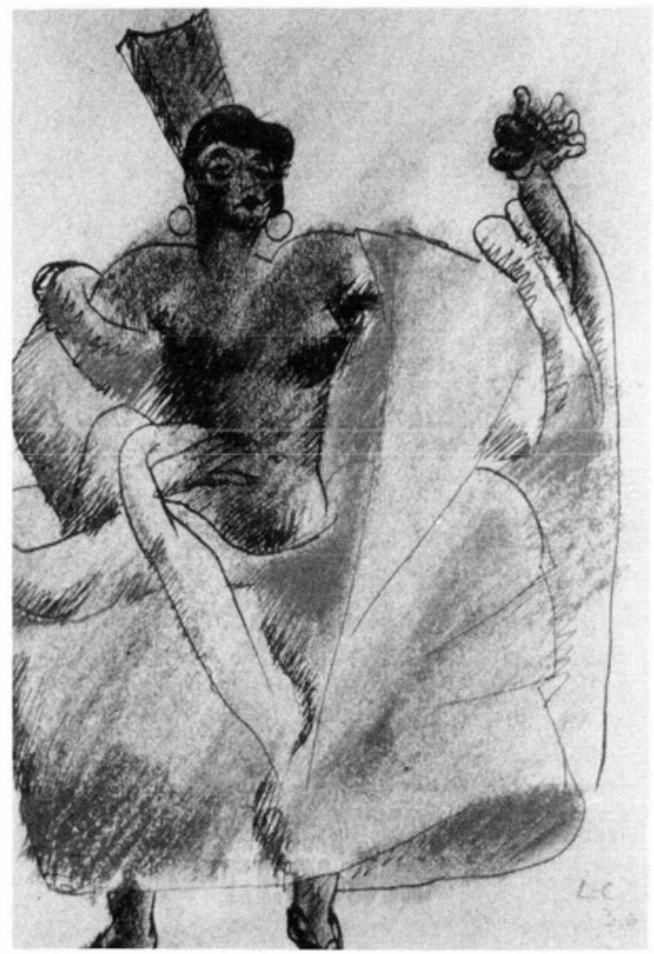

7. Bailarina de flamenco, 1950.

Pastel sobre papel. 
DOI: http://dx.doi.org/10.22201/iie.18703062e.1990.61.1579

8. Desnudo, 1950.

Lápiz carboncillo sobre papel.

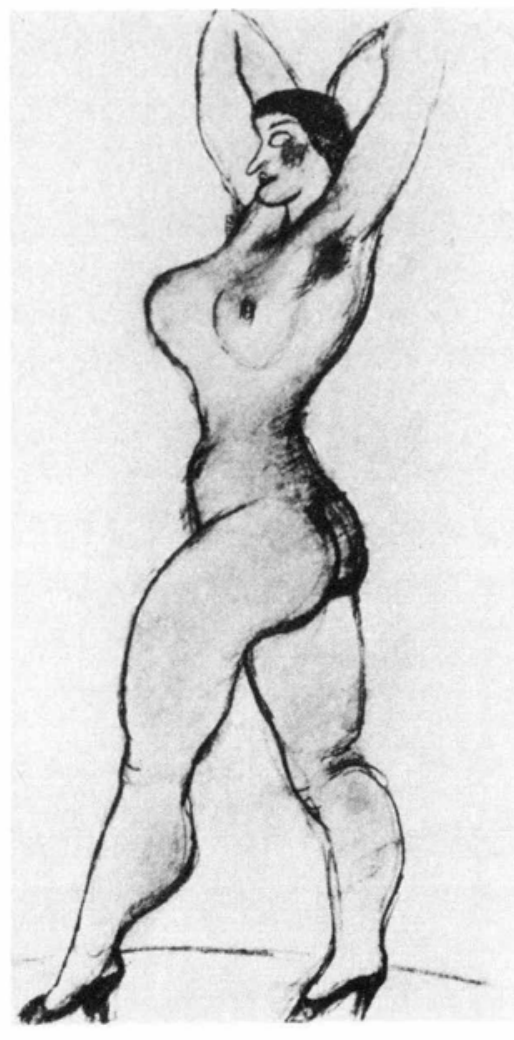

9. Mujeres haciendo el amor, s.f.

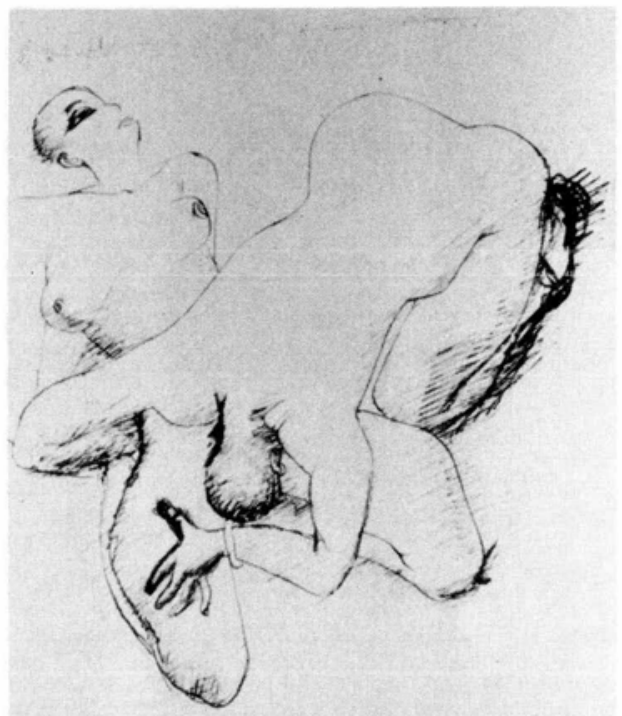

Lápiz carboncillo sobre papel. 
DOI: http://dx.doi.org/10.22201/iie.18703062e.1990.61.1579

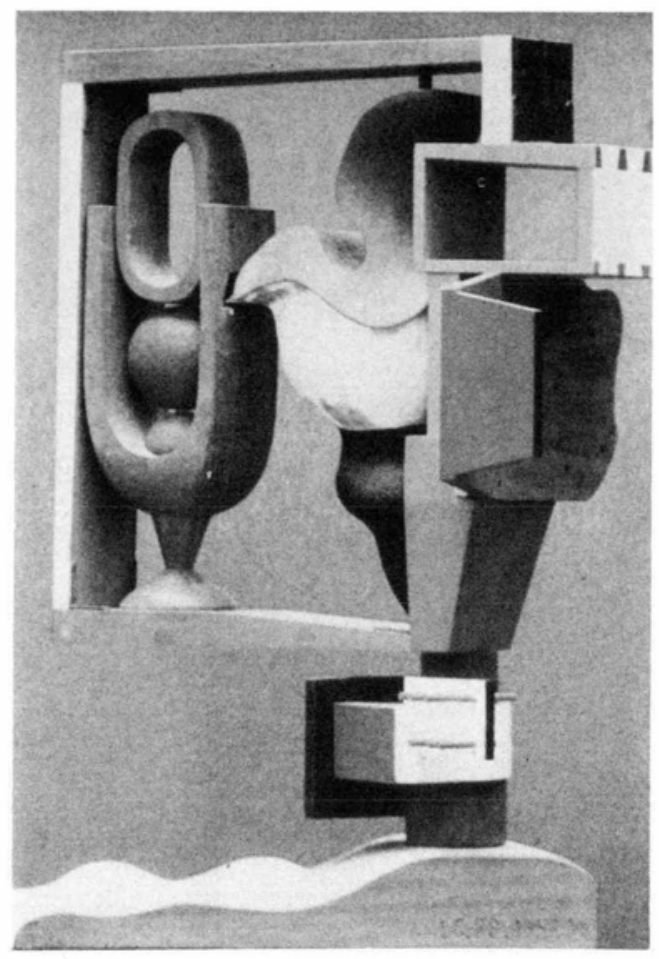

10. Formas en el espacio, s.f. Madera policromada.

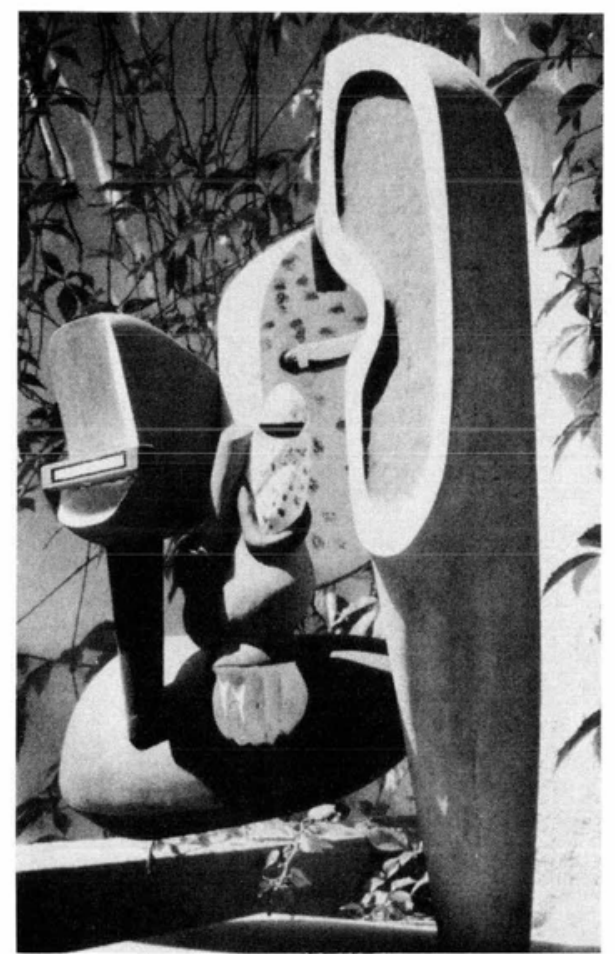

11. Escultura de madera policromada, 1945. 
DOI: http://dx.doi.org/10.22201/iie.18703062e.1990.61.1579

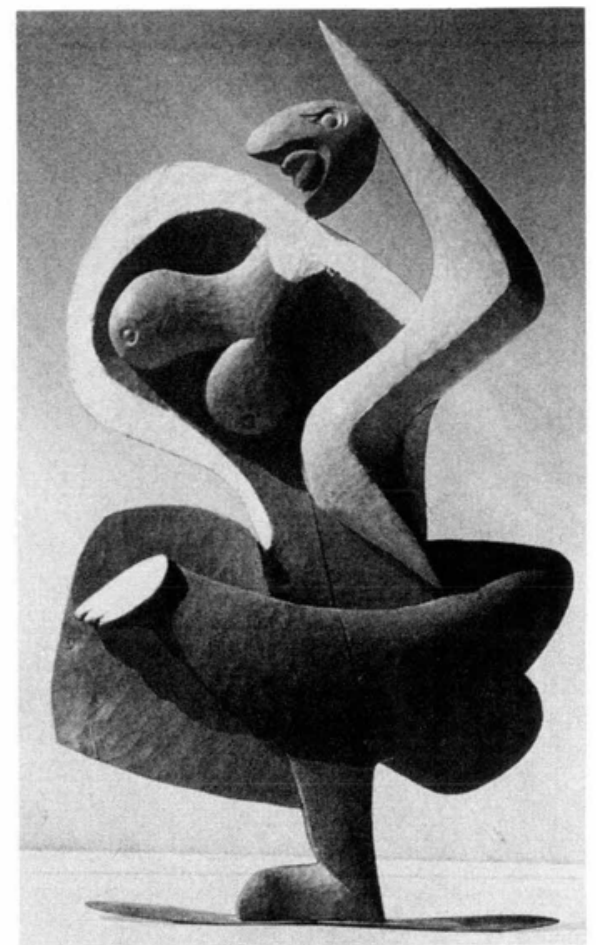

12. Bailarina, 1962.

Madera policromada.

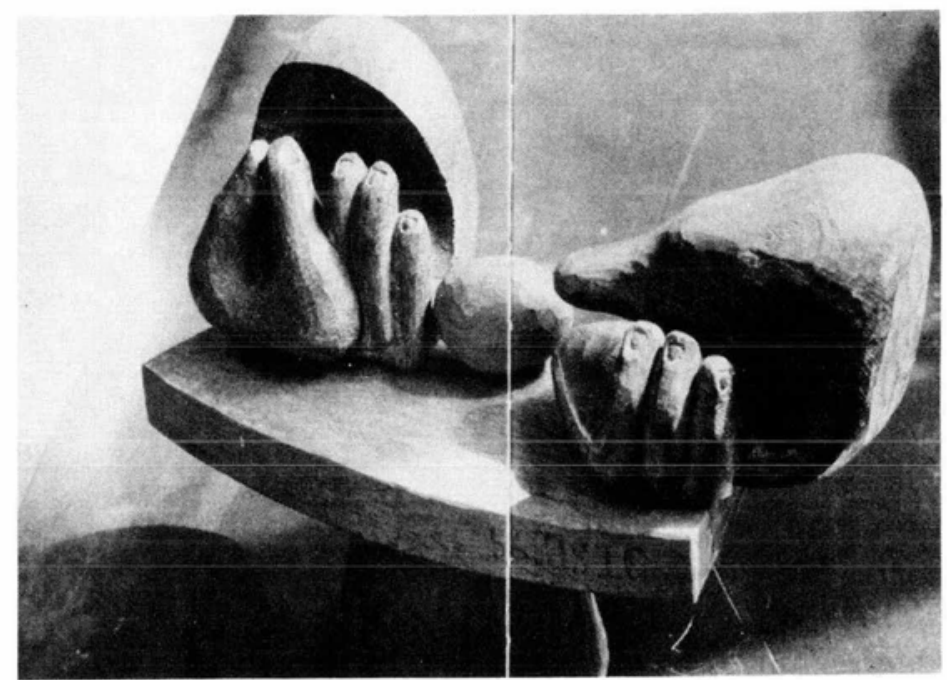

13. Manos, 1950.

Madera al natural. 
DOI: http://dx.doi.org/10.22201/iie.18703062e.1990.61.1579

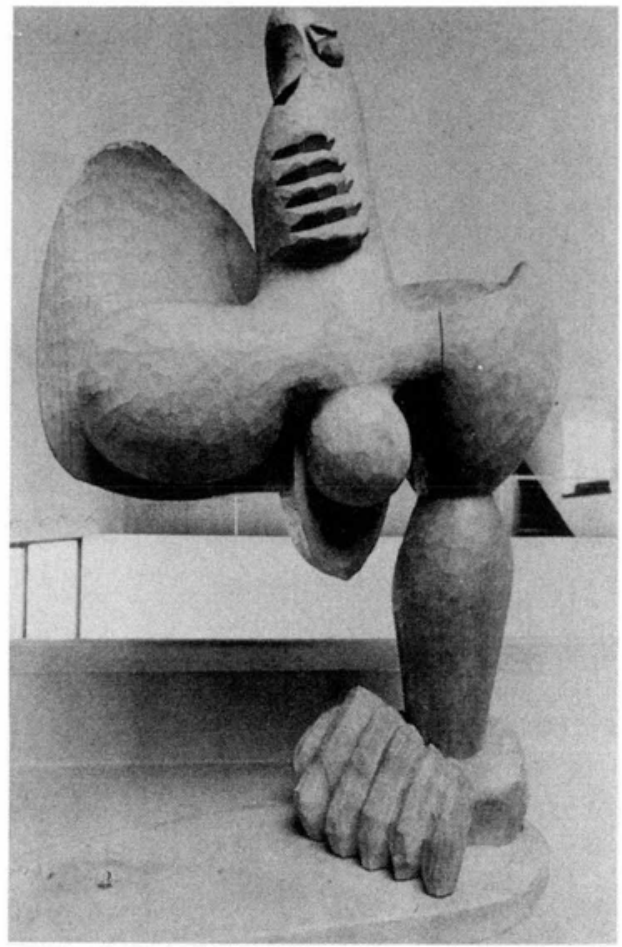

14. Tótem, 1950.

Madera al natural.

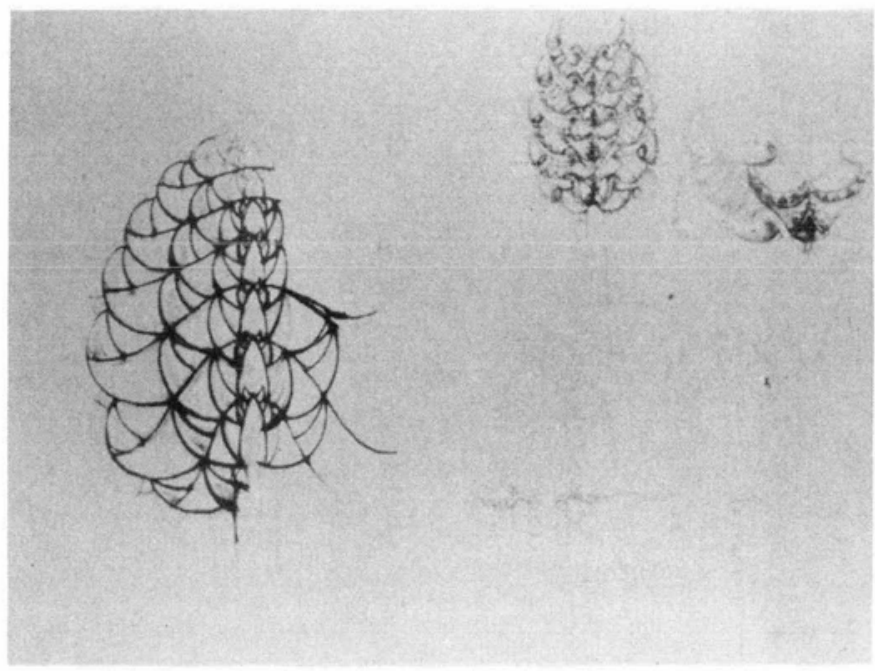

15. Estudios de una bellota, 1904.

Lápiz / papel. 
entrar en la dimensión de la arquitectura. Le Corbusier va a revolucionar el término y la dimensión de la arquitectura al incluir dentro de ella no sólo las construcciones dedicadas a la vivienda, sino todo objeto que sea bañado por la luz.

Formas en el espacio realiza íntegramente aquella afirmación lecorbusiana de que los ejes se utilizan como disciplina básica de orden, sustentada por el contraste potencial entre las longitudinales y las transversales. A pesar de que intervienen en esta obra diversas formas curvilíneas y ondulaciones, ejes reguladores, dominan las rectas verticales y horizontales. Estas enmarcan los curiosos "animales" o "gérmenes" que se mueven en su interior, dándole además de una acentuación escultórica, un "aire pictóri$c^{n}$ al analogarlas con la superficie de una hoja o una tela. No obstante presentar tal anfibología, esta escultura realiza estupendamente lo que el artista suizo-francés expresaba sobre el color, "expresión inmediata y espontánea de la vida", ${ }^{15}$ "desde que debuté como arquitecto, utilicé el color (el rojo, el azul, el amarillo) para calificar y clasificar las funciones orgánicas de la arquitectura, es decir la estructura, la opacidad de los muros, ...la circulación... ${ }^{16}$ Formas en el espacio es una excelente escultura purista pictórica-arquitectónica. Su división volumétrica está dada por el color que acentúa la "personalidad sensitiva" de cada cuerpo y de los prismas que integran su totalidad compartimentada. A propósito de esa capacidad "divisoria" del color, escribió: "La policromía arquitectónica se adueña de un muro entero o de una forma menor y lo califica con la potencia de la sangre o la frescura del rezo, la radiancia solar, la profundidad del cielo $o$ del mar."17 "La policromía es un medio tan potente como el plano y el corte. ${ }^{\text {n18 }}$ En la parte inferior de la obra persisten las ondulaciones de los primeros cuadros puristas de los años veinte. Ellas atenúan el juego de tensiones de la parte superior, de la misma manera que en la época purista. Formas orgánicas y formas geométricas coloreadas crean un contrapunto infinitamente exacto y vital en el que predomina, no obs- tante, la ortogonalidad, por así decir, carcelaria,que regula con severidad el espacio.

A pesar del rigor administrador en sus espacios, Le Corbusier no pudo sustraerse a la influencia renovadora del primitivismo que inyectó nueva sangre a la obra de no pocos artistas de principios de este siglo. No pudo

${ }^{15}$ Ibidem
${ }^{16}$ Ibidem
${ }^{17}$ Ibidem.
${ }^{18}$ Ibidem. 
prescindirse de la necesidad de un nuevo aire que experimentara la sufrida Europa de entre-guerras.

Si no a la par del Picasso de 1907 y el de la tercera década del siglo, entre los años cuarenta y cincuenta vemos surgir de la avidez plástica de Le Corbusier algunas magistrales obras en madera poco policromada, que a diferencia de las antes consideradas, se acercan más a la animalidad elemental humana visceral, excretora y digestiva...: "Todo objeto arquitectónico es un acontecimiento plástico y orgánico." ${ }^{19}$

Entre esas obras encontramos, sin embargo, algunas diferencias. Existen las esculturas de movimiento centrípeto-centrífugo simultáneo y las que, plantadas bruscamente a partir de una curva fundamental, se cierran en sí mismas. La Bailarina, de 1962 (fig. 12), bella escultura policromada cuya composición espiral básica le infunde gran dinamismo, es una excelente contraposición de vectores en diversas direcciones. Tiene la estirpe del fuego artificial y el vértigo del torbellino. La parte anterior ofrece dos curvas muy acentuadas de cuyo encuentro surge un "rayo" violeta, signo de pronunciación de la huída ascendente, "frenada" por el "pecho" de la bailarina que guarda sus dos senos como una semilla que se dividiera en el principio de la germinación.

La "pierna" izquierda se levanta y cierra magistralmente la composición. Encierro y liberación subrayan la obra. En ella sólo existen rectas por consecuencia, pero su predominante son las curvas. De ahí que al partir de la espiral ofrezca tal sensación de movimiento y tienda a elevarse, violentando el espacio hacia los lados.

Sus Esculturas orgánicas de madera fueron ejecutadas por Savina, el gran ebanista francés que trabajó con Le Corbusier de 1945 a 1965, año de la muerte del arquitecto. Curvas merodean la madera, material absolutamente cálido, circulatorio, neutral, maleable dentro de su suave y tibia solidez.

Entre las piezas cimeras que los dos artistas produjeron, se encuentran unas Manos, de 1950 (fig. 13) de rara hermosura primitivo-expresionista que, sin embargo, alcanzan un refinamiento cinético y esencial extremo. También hay un Totem, de 1950 (fig. 14), todo pulposo y palpitante. La capacidad prensora de las manos paipita tranquila en la brusca intimidad de sus formas; de nuevo el contrapunto, de nuevo la oposición como estadio supremo de la riqueza formal e ilusoria en la percepción. Las "palmas" de esas manos, dos pirámides horizontales cuyos vértices son

${ }^{19}$ Ibidem, p. 21. 
curvos, se oponen a dedos ingenuos e inexpresivos. Tensión, contención, un estar ahí en constante paradoja espacial y matérica formal. Para Le Corbusier, la mano era el signo de la esperanza y el "...estado de equilibrio de los gestos surreales que están por encima del orden, cuya misión es calcular.... ${ }^{20}$ Por eso quizá, siempre dibujó y mandó esculpir las manos en actitud envolvente, generadora. Nunca las ofrece abiertas como esquema con cinco protuberancias y un cuerpo único, sino dobladas, con una magnífica capacidad expresiva instantáneamente cambiante. Así como la curva, magna dimensión expansiva y al mismo tiempo hermética, esotérica y clara como el vientre de una mujer encinta, el subconsciente fue para Le Corbusier un punto central del misterio y el infinito... La mano tiende, más que a la rectitud, a doblarse, a oscurecer su interior cálida o violentamente; recordemos que al advenir la muerte, las manos se doblan para siempre.

La línea curva alcanzó significados místicos y metafísicos determinantes en su arquitectura, lo cual se proyecta en esculturas de seres primitivos de ciencia-ficción que están muy próximas de las manos que acabamos de ver. Se trata de piezas de madera cuya amplia composición se cierra en sí misma, adquiriendo la "inquietante extrañeza" de los totems. Aparte de su gran plasticidad, son esculturas orgánicas de las que Le Corbusier escribió: "este tipo de escultura entra en lo que yo llamo plástica acústica, es decir, formas que emiten sonidos y a la vez escuchan". ${ }^{21}$

Así como en Ronchamp, Chandigarh, y en algunos signos como $E l$ Modulor, que aparecen en algunos muros de la Unidad Habitacional de Marsella, podemos hablar de una arquitectura escultórica de signos cuyo significado nos sobrepasa. Sus esculturas de madera sin policromar también nos trascienden en el reto de las dualidades a las que nos someten: ¿̇de no ser en la magnitud del círculo o la esfera en qué otra realidad sería aprehensible la dimensión infinita de la curva? Nos es asequible en la concreción de la práctica artística, y en donde más la podemos tener cerca de nosotros es en el paisaje y en las obras de la arquitectura y de la ingeniería (los grandes puentes con su perspectiva curva, a veces feroz, nos dan idea de la potencia de esa línea). También accedemos a ella invisiblemente a través de sentimientos o estados expansivos como la alegría, el gozo, la euforia, la risa y todo aquello que en nuestro interior no tiende a la recta, a la división o el rigor intelectual. La tristeza

\footnotetext{
${ }^{20}$ Le Corbusier-Savina, Op cit., p. 8.
${ }^{21}$ Ibidem.
} 
no dibuja curvas expansivas. La angustia es vertical y punzante aunque, incisiva, altera nuestro biorritmo en sentido descendente.

La vida, así como el gozo creador, está íntimamente relacionada con la línea curva. No podemos imaginar la totalidad de la vida en rectas. La vida como origen, y el gozo, son luz. De ahí que Le Corbusier afirmara constantemente, que el sol y su luz rigen las emociones psicofisiológicas fundamentales.

\section{Conclusiones}

Una de las grandes virtudes de Le Corbusier fue haber logrado una perfecta coherencia entre su obra teórica y su práctica artística. Desde el comienzo de su carrera, que despuntó con un enfrentamiento realista muy minucioso con la naturaleza y el mundo, sus ideas fueron abriéndose bajo el sol de la certeza y de la seguridad necesaria para convertirlas en obra. Así, desde el boceto de una bellota (fig. 15) hasta los últimos planos arquitectónicos, los edificios y urbes enteras realizadas, sin descartar sus esculturas, están unidos por la línea común del Purismo, teoría inicialmente pictórica.

El Purismo fue la teoría ascética del afán de reducir los objetos a su esencia formal-figural, resaltando las tensiones entre los mismos y las de éstos con el espacio, ámbito con propia sensibilidad. Sin embargo, aún siendo un sistema de pensamiento casi monacal, casi de "torre de marfil" y de arte por el arte si se le hubiese dejado escrito sobre el papel, el Purismo desbordó las naturalezas muertas en las que fue practicado por vez primera. Su proyección no fue solamente hacia la búsqueda de una nueva belleza surgida de una síntesis geométrica que manejó las tensiones, la sensación y la emoción plástico-espacial de manera diferente, sino que alcanzó la corporeidad de la escultura y la belleza monumental, unida a la fundamental utilidad de la arquitectura (una verdadera esculto-arquitectura en muchas de las obras del maestro). Es decir, el Purismo lecorbusiano no fue como la "pura pureza" o el concepto de gloria, estáticos, sin vida, sin frutos vivos. Fue, después de una época de catástrofé, una gran necesidad de crear un estado cero que partiese de lo elemental, lo cual forzosamente implicaría una negación y pleito con lo hasta ese momento establecido por la tradición occidental, para ver con claridad lo que la elementalidad y la sencillez aportaban a un mundo por construir, en su evidente verdad. Pero con una super-proyección social y, por lo tanto, cotidianamente útil. Mucho más útil, en ese sentido, que el pro- 
pio cubismo, hermano suyo en los intentos de diseccionar los elementos de la realidad para presentar en un solo plano, no sólo la anterioridad, sino lo posterior, "lo arriba" y "lo abajo" de los objetos.

El Purismo de Le Corbusier conjunta dos niveles hasta entonces no fusionados por otras corrientes: el de la pureza geométrica bajo la intensidad lumínica en el color y en la arquitectura (en ésta por el juego de las formas bajo la luz) y una implicación y compromiso morales ineludibles. Orden y moral; arte constructivo y moral.

Por otro lado, en el terreno de la pintura, Le Corbusier nos volvió linealmente visible el tiempo, ya que al reducir a su más esencial simplicidad los objetos en figuras geométricas, tensas a base de diferentes colores y en donde reina la línea curva, nos deja sentir el tiempo como transcurrir sin límites, lo "aplana" y lo vuelve lineal en ritmo lento. Así, permite ver y sentir, proyectadas estupendamente en la pintura purista ( $y$ también en la escultura, aunque con variantes), el movimiento y la velocidad de nuestra propia percepción. Obra y espectador se convierten en espejos que se miran mutuamente.

En lo referente al dibujo, manejó campos de fuerza vectorial y plástica en los que unas veces la línea circunda, "dibuja" propiamente, y otras, sólo pone límites informales a manchas de color desbocadas, víctimas de su propia libertad y turbulencia. Bailarina de flamenco lo demuestra.

En la escultura trabajó dos campos, uno primitivo-geométrico, otro primitivo-orgánico. Ambos reparten el espacio exterior a base de sensaciones creadas a partir de sus propios volúmenes pintados. Propició el nacimiento de una nueva belleza con sus esculturas arquitectónicas habitables, con lo cual llega a una mimesis natural entre habitante y obra habitada.

Su meta más grande fue la captación constante de la vibración de las formas bajo la luz y, lo que es más amorosamente espléndido, nunca descuidó que la expresión de la emoción plástica llegara, con toda su vibración y vida, íntegra al espectador, y de que éste la experimentara a través de ojos y cuerpo, en conmovida unidad, en el espacio sensible. 